Research paper

\title{
Atmospheric and terrigenous metal accumulation over 3000 years in a French mountain catchment: Local vs distal influences
}

\author{
Sophia V. Hansson ${ }^{\mathrm{a}, *, 1}$, Adrien Claustres ${ }^{\mathrm{a}}$, Anne Probst ${ }^{\mathrm{a}}$, François De Vleeschouwer ${ }^{\mathrm{a}}$, \\ Sandrine Baron ${ }^{\mathrm{b}}$, Didier Galop ${ }^{\mathrm{c}}$, Florence Mazier ${ }^{\mathrm{c}}$, Gaël Le Roux ${ }^{\mathrm{a}}$ \\ a EcoLab, Université de Toulouse, CNRS, INPT, UPS, Avenue de l'Agrobiopole, 31326 Castanet Tolosan, France \\ ${ }^{\mathrm{b}}$ Laboratoire des Travaux et Recherches Archéologiques sur les Cultures, les Espaces et les Sociétés, Université Toulouse Jean-Jaurès, CNRS UMR 5608, Maison de la \\ Recherche, 5 Allée Antonio-Machado, 31058, Toulouse, France \\ c GEODE UMR 5602, Labex DRIIHM (OHM Haut Vicdessos), CNRS, Université Jean-Jaurès, 5 Allée Antonio-Machado, 31058, Toulouse, France
}

\section{A R T I C L E I N F O}

\section{Keywords:}

Metals and metalloids

Legacy pollution

Peat

Mountain soils

Lead isotopes

Remobilization

\begin{abstract}
A B S T R A C T
In this paper we report analyses of four peat cores taken from a mountain valley in the French Pyrenees where ancient metallurgical and agro-pastoral activities have occurred. By combining a range of geochemical and chronological proxies we investigated (1) the importance of PHTE (Potentially Harmful Trace Element) accumulation during pre-industrial times compared to recent accumulation, and (2) the intimate relationship between landscape use and terrestrial PHTE transfers. We show how long human-environment interaction in mountain environments and pre-industrial anthropogenic activities led to PHTE accumulation equal to or even exceeding that of modern times. Atmospheric contamination by PHTE occurred throughout $500 \mathrm{BC}-\mathrm{AD} 500$ for lead $(\mathrm{Pb})$ and antimony (Sb), AD 1200-1600 for only $\mathrm{Pb}$, and the last 150 years for $\mathrm{Pb}, \mathrm{Sb}$ and copper $(\mathrm{Cu})$ combined. Lead isotopes allowed determination of the impact of $\mathrm{Pb}$ contamination from significant local mining and metallurgical activities during the Middle Ages. An estimation of PHTE inventories derived from atmospheric deposition suggests that $85 \%$ of $\mathrm{Pb}$ accumulation occurred before $\mathrm{AD} 1800$, thus highlighting the influence of past local activities to the accumulation of atmospheric contaminants compared to that of more recent periods. Enhanced erosion input to one of the mires is evident from AD 1600 to 1950, and intensive grazing coupled with forest clearings are the likely cause of these rapid transfers of natural PHTE and previously stored $\mathrm{Pb}$ to downstream mires. Remobilized $\mathrm{Pb}$ in the impacted peatland represent at least one third of the total $\mathrm{Pb}$-inventory, suggesting that terrestrial transfers were important and acting as hotspot sources of PHTE accumulation.
\end{abstract}

\section{Introduction}

Anthropogenic fluxes of up to 62 chemical elements surpass their corresponding natural fluxes (Sen and Peucker-Ehrenbrink, 2012). Among those elements some metals and metalloids, such as lead $(\mathrm{Pb})$ or antimony ( $\mathrm{Sb})$, are considered as potentially harmful trace elements (PHTE; Plant et al., 1997) with limited or no biological function. Previous studies have clearly shown that widespread PHTE contamination of especially $\mathrm{Pb}$, as recorded in ice cores (Hong et al., 1994; Rosman et al., 1997; Zheng et al., 2007), peat cores (Shotyk et al., 1998; Martinez Cortizas et al., 2002) and in lake sediments (Renberg et al., 1994; Camarero et al., 1998), occurred from the onset of metallurgical processing leaving a millennial scale pollution history.

Due to their geological features, e.g. ore deposits, mountain environments have been exploited since the beginning of the practice of metallurgy. Pre- industrial contamination of $\mathrm{Pb}$ has been evidenced in several European mountain ranges (De Vleeschouwer et al., 2014 and references therein) and European medieval mining and metallurgy is considered to be the cradle of the industrial contamination by PHTE in general, and $\mathrm{Pb}$ in particular (Brännvall et al., 1999). Based on our review of available literature and our own unpublished data, European mountain soils stored at least $800 \mathrm{mg} \mathrm{m}^{2}$ of locally derived $\mathrm{Pb}$ before the Industrial Revolution (i.e. prior to 1800; see Table 1 and Table S1 in Supplementary information - SI), sometimes equal to or exceeding industrial contamination. Yet, even though PHTE are known to be concentrated in mountain soils, the legacy of trace metal stocks in mountain zones, in relation to environmental changes, is still poorly understood (Le Roux et al., 2010; Stankwitz et al., 2012).

The Pyrenees are no exception to this pre-industrial contamination as many mining and metallurgical sites were present in the region, of which some are dated as far back as the Bronze Age (Monna et al.,

\footnotetext{
Abbreviations: PHTE, potentially harmful trace element; EF, enrichment factor; AR, accumulation rate; ESLP, European Standard Lead Pollution

* Corresponding author.

E-mail address: sophia.hansson@bios.au.dk (S.V. Hansson).

${ }^{1}$ Current address: Department of Bioscience - Arctic Research Centre, Aarhus University, Fredriksborgvej 399, Roskilde DK-4000, Denmark.
} 


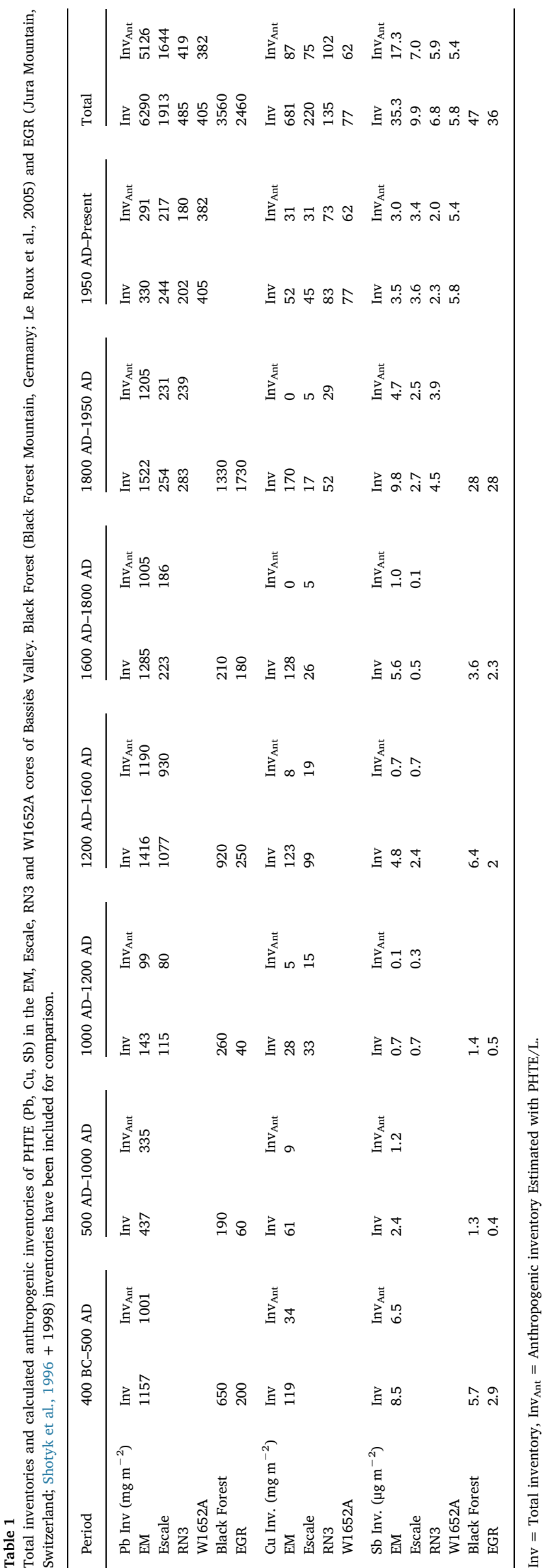

2004a; Galop et al., 2013). Bassiès valley is located in the Vicdessos region within the Pyrenees Mountain Range (Ariège, FRANCE). Ancient human activities i.e. forest clearings, charcoal production and cattle grazing, have been ongoing since the late Neolithic (Galop and Jalut, 1994; Galop, 1998) and were intensified during the Middle Ages in order to supply charcoal for metallurgical activities. On the western side of the valley (Aulus-les-Bains mining district) copper- $(\mathrm{Cu})$, silver$(\mathrm{Ag})$ and $\mathrm{Pb}$-ores were exploited, while iron $(\mathrm{Fe})$ ores were extracted and smelted on the eastern side (Dubois, 1999). The processing and smelting of ores could potentially have caused local atmospheric contamination of PHTE (Bindler et al., 2011; Karlsson et al., 2015). Further to this, in the Bassiès catchment, erosion has been closely related to cattle grazing, i.e. with the abandonment of intensive pastoral activities in the 1960s a clear decrease in erosion rates have been shown (Galop et al., 2011).

Remobilization of contaminants stored in mountain organic soils can influence contaminant loads in fluvial systems and downstream mountain lakes (Kaste et al., 2003). Watershed inventories of PHTE have shown that $\mathrm{Pb}$ related to industries and leaded gasoline, and $\mathrm{Pb}$ stored in Pyrenean soils, was remobilized and transferred to downstream lakes several years after the contamination occurred (Bacardit and Camarero, 2010). The quality of lake sediments and water could therefore be impacted by remobilized PHTE which could also be further transferred into the aquatic food chains. For example, it has been shown that contamination of $\mathrm{Pb}$ has reached aquatic mosses (Camizuli et al., 2014) and even high trophic level organisms such as trout in or near mining environments (Monna et al., 2011; Paris et al., 2015).

Geochemical records of contamination from peatlands often are used to estimate the deposition of PHTE (i.e. atmospherically derived contamination only when the peatlands are ombrotrophic; Hansson et al., 2015 and references therein). Since elements associated with soil dust (Ti, Rare Earth Elements - REE), including PHTE (Pb, $\mathrm{Sb}, \mathrm{Cu}$ ), are relatively retained within the peat column, peat chemical profiles provide valuable records of PHTE accumulation and enable reconstruction of pollution history.

In this study, we investigated PHTE accumulation over time in four peat profiles from a small mountain valley in the Pyrenees that has undergone more than 2000 years of human activities. The objective was to show the long human-environment interaction in mountain environments and the influence that pre-industrial anthropogenic activities have had on PHTE accumulation. Specifically, we studied: 1) The importance of PHTE accumulation during preindustrial times compared to recent PHTE deposition, and 2) The close relationship between past human activities and the remobilization of terrestrial PHTE within this high mountain catchment. We show that the impact of pre-industrial to recent human activities in European mountains could be equal to those of the Neolithic or the Bronze Age-Antiquity-era. Further, and more importantly, we show that these recent human activities were not necessarily restricted to merely the last 50 to 200 years but rather extending over centennial scales.

\section{Methods}

\subsection{Sampling and handling}

We selected four peat bogs and mires, i.e. minerotrophic peatlands with ombrotrophic near surface characteristics in the form of Sphagnum hummocks, in the Bassiès valley. All sites were at close proximity to each other to guarantee a representative spatial coverage over the watershed (Fig. 1). Our own geological survey and French Geological Survey missions showed that, contrary to the western opposite slope, there is no ore mineralization in this valley. RN3 is a blanket bog located on a plateau, isolated from lateral water and mineral input. Escale and W1652 are located over flat areas. The last mire, called Etang Mort (EM), is located in a small catchment within the valley and represents more than 3000 years of continuous peat accumulation. The age of the 


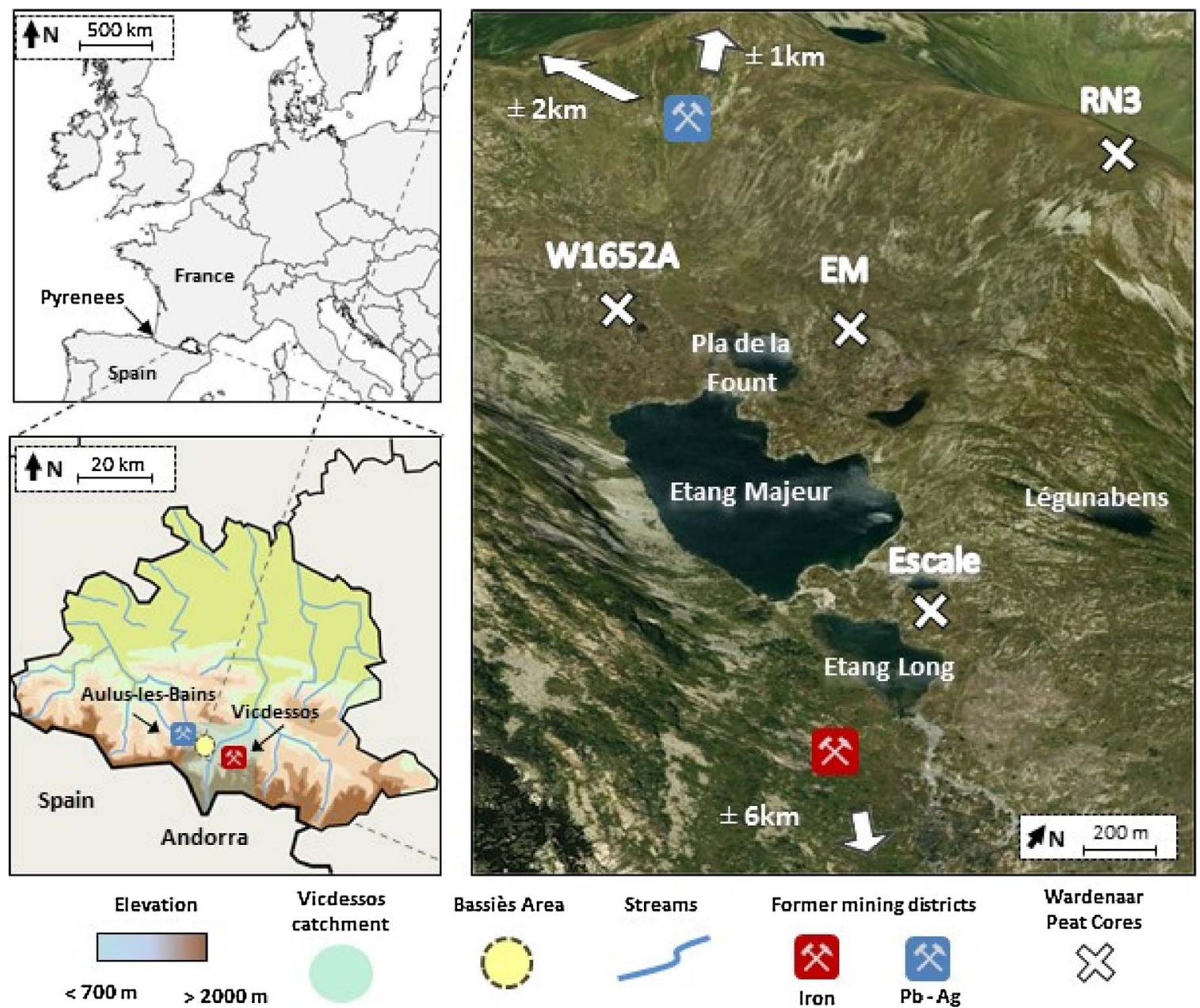

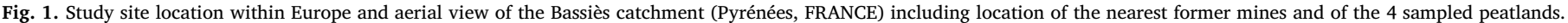

oldest measured sample, i.e. measured calibrated calendar years in the bottom of each core, was 2750-2420 BC, 1190-1000 BC, 990-850 BC, AD 1390-1790 for W1652, EM, Escale and RN3 respectively. Specific information on the peat profiles is reported in Table S2 in SI.

Although the bogs were minerotrophic, as some fluvial input may occur, all peat cores were collected from Sphagnum-dominated hummocks with presence of only unsupported lead-210 down to $50-100 \mathrm{~cm}$ depth. For this reason, all peat cores should thus be considered as minerotrophic peat with ombrotrophic characteristics. Hummocks at all four sites were sampled from 2010 to 2012, using a Wardenaar corer (Wardenaar, 1987) and prepared following customary protocols (Givelet et al., 2004; Le Roux et al., 2010). Briefly, peat cores were carefully packed in plastic bags in the field, transported back to laboratory and stored frozen until further processing. The cores were then sliced frozen into $1 \mathrm{~cm}$ slices using a stainless steel band saw, subsampled with a ceramic knife and then freeze-dried. Finally the samples were milled using an electric mill for organic rich samples and an agate mortar for mineral rich samples.

\subsection{Dating and age-depth modelling}

Samples dedicated to radiocarbon dating consisted of Sphagnum leaves and stems. These were identified and extracted from $1 \mathrm{~cm}^{3}$ of bulk peat following the protocol by Mauquoy et al. (2004). We estimated recent accumulation using ${ }^{210} \mathrm{~Pb}$ gamma measurements on peat powder. To ensure a valid chronology and correct for any subsurface peaks in ${ }^{210} \mathrm{~Pb}$ activities related to changes in peat density, or potential downward mobility of ${ }^{210} \mathrm{~Pb}$, age-depth models were estimated based on a combination of both ${ }^{210} \mathrm{~Pb}$ CRS (Constant Rate of Supply) model (Appleby, 2002) and CLAM radiocarbon age depth model (Blaauw, 2010). Uncertainties of the ${ }^{210} \mathrm{~Pb}$ ages were calculated using Matlab with MonteCarlo simulations according to Binford (1990) and combined with the radiocarbon uncertainties in CLAM to build a robust age depth model (raw dates and details on age-depth models are reported in SI).

\subsection{Geochemistry}

Approximately $100 \mathrm{mg}$ of dried and homogenized peat was digested in PFA vials in a clean room using a $\mathrm{HF}-\mathrm{HNO}_{3}-\mathrm{H}_{2} \mathrm{O}_{2}$. Digestion. The digestion succession protocol is modified from Le Roux and De Vleeschouwer (2010), adding a $\mathrm{HCl}-\mathrm{HNO}_{3}$ step when particles remained. Two certified reference materials of peat (NIMT and NJV-942, recovery data - see Table S4 in SI) were also digested to assure digestion- and analytical quality. All the digestion processes were made using suprapur analytical grade reagents $\left(\right.$ MERCK $\left.^{\odot}\right)$. PHTE were analyzed using a quadrupole ICP-MS (Agilent 7500ce). Pb isotopes $\left({ }^{206} \mathrm{~Pb}\right.$, ${ }^{207} \mathrm{~Pb}$ and ${ }^{208} \mathrm{~Pb}$ ) on peat samples were analyzed using a High Resolution ICP-MS (Thermo Element II XR). Individual sample bracketing with certified NIST NBS-981 was done to correct for mass shift according to Krachler et al. (2004). Blank values were negligible and measurements of CRM NIMT and NJV-942 were in good agreement with certified values for $\mathrm{Pb}, \mathrm{Sb}$ and $\mathrm{Cu}$, and $\mathrm{Pb}$ isotopes (See Table $\mathrm{S} 4$ in $\mathrm{SI}$ ). Some $\mathrm{Pb}$ isotopes were also measured on local ores from the Aulus-les-Bains mining district, using a Thermal Ionization Mass Spectrometer (TIMS) without any spiking method (for inter-comparison between the two 

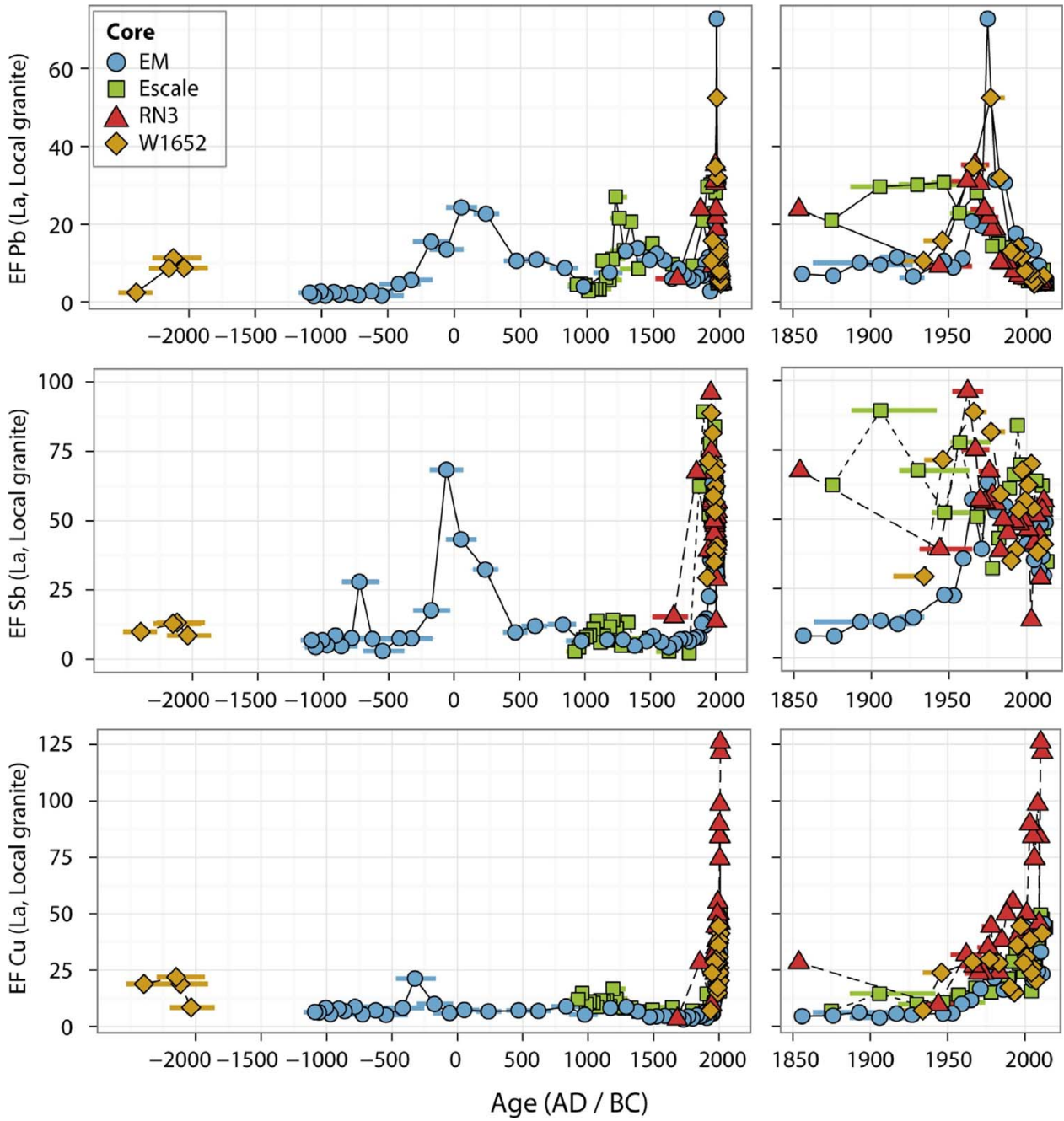

methods, see SI and Krachler et al., 2004). Repeated measurements of NIST NBS $981 \mathrm{~Pb}$ reference material yielded a reproducibility $(2 \mathrm{x}$ standard deviations) better than $0,002 \%$ for the reported $\mathrm{Pb}$ isotopes ratios (data and details are reported in SI).

\subsection{Geochemical tools}

Enrichment Factor (EF) is a simple geochemical indicator tool, which helps define an enrichment relatively to a reference value, and it has been widely used in different research areas (Camarero et al., 1998; Martínez Cortizas et al., 2002). PHTE ratio to Lanthanum (La) in the local rock (Bassiès Granite) was here used to calculate EF (Eq. (1)) as La is immobile within peatland profiles and few anthropogenic sources are present.

$E F_{\text {PHTE }}=\frac{[\text { PHTE }]_{\text {Sample }} /[\text { La }]_{\text {Sample }}}{[\text { PHTE }]_{\text {Granite }} /[\text { La }]_{\text {Granite }}}$

Accumulation rates (AR) of elements (in $\mathrm{mg} \mathrm{m}^{-2} \mathrm{yr}^{-1}$ ) were calculated (Eq. (2)) using peat bulk density (BD in g. $\mathrm{cm}^{-3}$; Givelet et al., 2004), PHTE concentration ([PHTE] in mg.kg ${ }^{-1}$ ), the thickness of the slice $(\mathrm{H}$ in $\mathrm{cm})$ and the age of the slice:

$A R_{P H T E}=\frac{10^{*}[P H T E]^{*} H^{*} B D}{A g e}$

\section{Results and discussion}

\subsection{Geochemical background}

Fig. 2. Enrichment Factors of $\mathrm{Pb}, \mathrm{Cu}$ and $\mathrm{Sb}$ relative to La (as the reference lithogenic element) and the local Bassiès Granite (as the reference material) against time in the 4 sampled cores. Horizontal bars represent the $95 \%$ confidence interval from CLAM age-depth model.

The local geochemical background was estimated from the oldest samples measured in the deepest layers of EM (dated from 1100 to $920 \mathrm{BC}$ to 920-750 BC) and W1652 (2260-2520 BC) cores. Background Pb AR in W1652 $\left(32 \mu \mathrm{g} \mathrm{m}^{-2} \mathrm{yr}^{-1}\right)$ was comparable to those measured in northern Spain before 1775-1670 BC $\left(\mathrm{Pb} \mathrm{AR}=32 \pm 30 \mu \mathrm{g} \mathrm{m}^{-2} \mathrm{yr}^{-1}\right.$; (Kylander et al., 2005) and in the range of other European records (Pb $\mathrm{AR}=1-40 \mu \mathrm{g} \mathrm{m}^{-2} \mathrm{yr}^{-1}$; Shotyk et al., 1998; Klaminder et al., 2003; Le Roux et al., 2005). In the oldest samples of the EM core (i.e. from 1190 $1000 \mathrm{BC} 1000 \mathrm{BCE}$ to $930-660 \mathrm{BC}$ ), EFs were stable and already enriched compared to local granite $(\mathrm{EF} \mathrm{Pb}=2 \pm 1 ; \mathrm{EF} \mathrm{Cu}=7 \pm 1 ; \mathrm{EF} \mathrm{Sb}=6 \pm 2$; $\mathrm{n}=7)$ and $\mathrm{Pb}$ ARs were higher than background European $\mathrm{AR}(\mathrm{Pb}$ $\mathrm{AR}=0.5 \pm 0.1 \mathrm{mg} \mathrm{m}^{-2} \mathrm{yr}^{-1}$ ). Antimony background AR in the W1652 core ( $\mathrm{Sb} \mathrm{AR}=0.6 \mu \mathrm{g} \mathrm{m}^{-2} \mathrm{yr}^{-1}$ ) was comparable to $\mathrm{Sb}$ AR in Swiss Jura (Shotyk et al., 1996) and Black Forest (EGR Sb AR $=0.60-0.67 \mu \mathrm{g} \mathrm{m}^{-2} \cdot \mathrm{yr}^{-1}$ around $2410-1840 \mathrm{BC}$ and $\mathrm{Sb} \mathrm{AR}=1.3 \mu \mathrm{g} \mathrm{m}^{-2} \mathrm{yr}^{-1}$ at $1050 \mathrm{BC}$; Black Forest Sb AR $=0.76-0.81 \mu \mathrm{g} \mathrm{m}^{-2} \mathrm{yr}^{-1} 1260-1090 \mathrm{BC}$ ), but lower than in the $\mathrm{EM}$ core ( $\mathrm{Sb} \mathrm{AR}=8 \pm 1 \mu \mathrm{g} \mathrm{m}^{-2} \mathrm{yr}^{-1}$ ). A small fluvial deposition of local soil could explain these higher background values of PHTE AR in the EM core, as any atmospheric source would likely have impacted and been seen at all sites. Lead isotopic ratios in the oldest samples of EM core were $1.197 \pm 0.001 \mathrm{in}^{206} \mathrm{~Pb} /{ }^{207} \mathrm{~Pb}$ and $2.062 \pm 0.002 \mathrm{in}^{208} \mathrm{~Pb} /{ }^{206} \mathrm{~Pb} \quad(\mathrm{n}=4)$, which is typical for granite signatures and similar with other pre anthropogenic records in Europe (Shotyk et al., 1996; Monna et al., 2004b). 

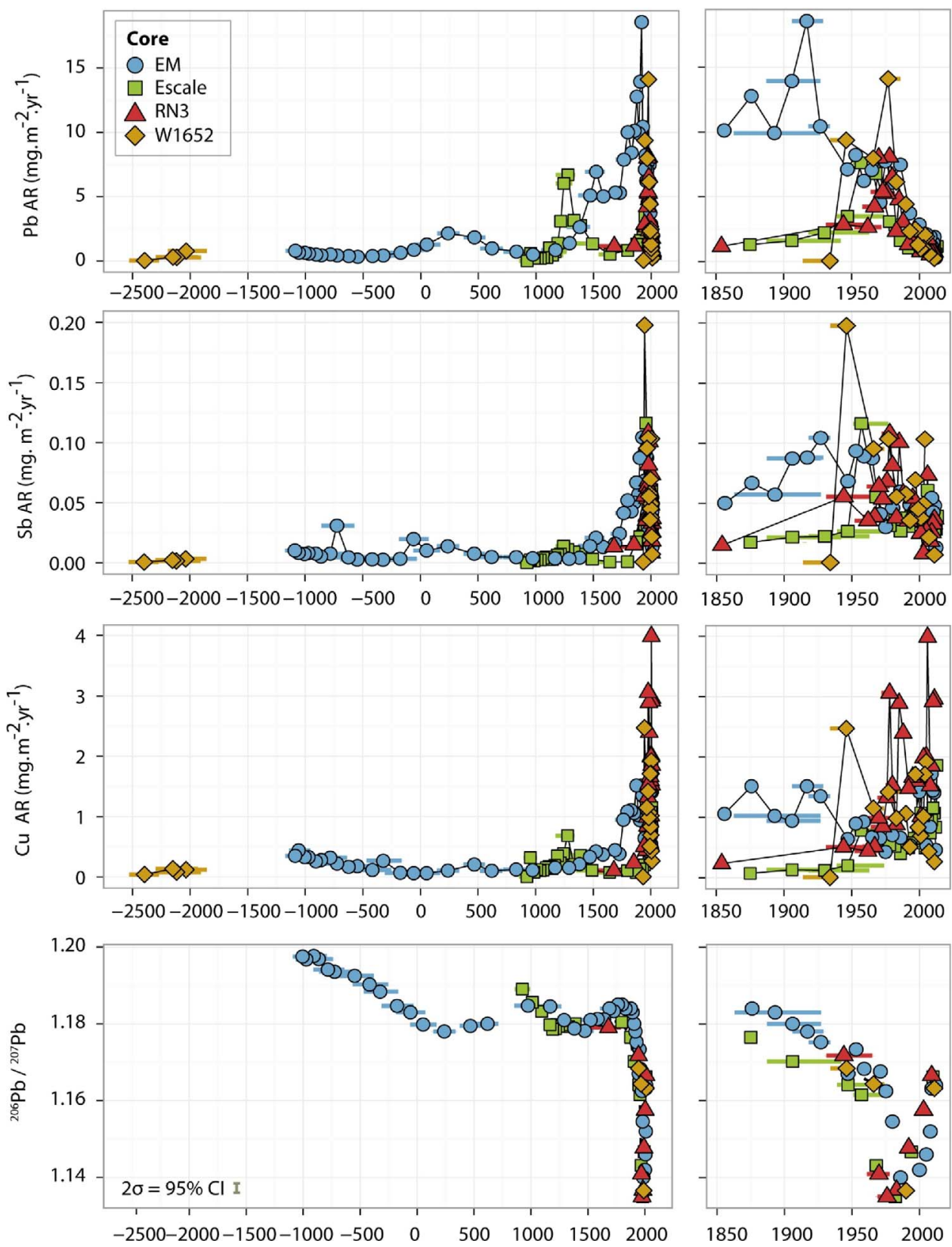

3.2. Contamination and metal accumulation over 2500 years

$\mathrm{Pb}$ contamination first occurred during the Iron Age and the Roman period from $600 \mathrm{BC}$ to $\mathrm{AD} 500$ as evidenced by a fivefold $\mathrm{Pb}$ AR increase and a shift in $\mathrm{Pb}$ isotope ratios towards anthropogenic signatures related to mining activities $\left({ }^{206} \mathrm{~Pb} /{ }^{207} \mathrm{~Pb}=1.179 \pm 0.001, \mathrm{AR}=2.0\right.$ $\pm 0.2 \mathrm{mg} \mathrm{m}^{-2} . \mathrm{yr}^{-1}, \mathrm{AD} 140-330$ to AD $280-560, \mathrm{n}=2$, Figs. 2-5). A $\mathrm{Pb} \mathrm{EF}$ increase up to 25 in a peat layers dated from $60 \mathrm{BC} / \mathrm{AD} 170$ to $\mathrm{AD}$ 140 - 330 confirms the widespread $\mathrm{Pb}$ contamination during the Antiquity, which is in good agreement with other European studies (Forel et al., 2010; Küttner et al., 2014). Sb AR and EF trends were synchronous with Pb evolution, showing the intimate relationship between these two PHTE. This is not the case of $\mathrm{Cu}$ which show no peak of contamination except a single pulse dated to 480-180 BC. Total inventories of PHTE throughout $400 \mathrm{BC}$ to $\mathrm{AD} 500$ in the EM core were 1.5-5 fold higher for $\mathrm{Pb}$ and 1 to 2 fold higher for Sb compared to Black Forest, Swiss Jura or Xistral mountains (Table 1 and Table S1 in SI). The presence of Sb enrichment and such high $\mathrm{Pb}$ accumulation (Shotyk et al., 1998; Forel et al., 2010) compared to other European records suggests a regional influence on the deposition (aeolian

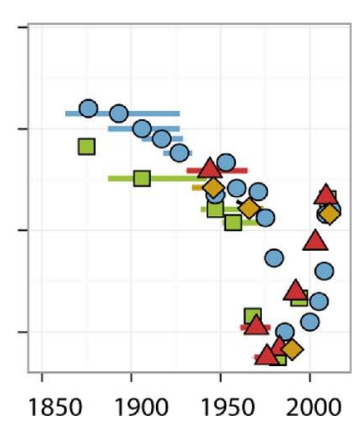

Fig. 3. Accumulation Rates (AR in $\mathrm{mg} \mathrm{m}^{-2} \mathrm{yr}^{-1}$ ) of the PHTE and ${ }^{206} \mathrm{~Pb} /{ }^{207} \mathrm{~Pb}$ against time in the 4 sampled cores. Horizontal bars represent the 95\% confidence interval from the CLAM age-depth model.

and/or fluvial) and PHTE input. The beginning of exploitation of local ores from Les Argentières mine is dated 366 to 192 cal BC (Py-Saragaglia et al., 2017). However, the $\mathrm{Pb}$ isotope signature of the Les Argentières ores (i.e. ${ }^{206} \mathrm{~Pb} /{ }^{207} \mathrm{~Pb}=1.171 \pm 0.001$ and ${ }^{208} \mathrm{~Pb} /{ }^{206} \mathrm{~Pb}=2.099 \pm 0.001, \quad \mathrm{n}=3$ ) does not match with the signature in the peat layers (Munoz et al., 2016). Instead the peat is closer to the signature of widespread Roman contamination (i.e. ${ }^{206} \mathrm{~Pb} /{ }^{207} \mathrm{~Pb} \approx 1.179$; Forel et al., 2010) as well as to several local ores from the Aulus-les-Bains mining district whose exploitation is mainly focused to the Middle Ages (i.e. ${ }^{206} \mathrm{~Pb} /{ }^{207} \mathrm{~Pb} \approx 1.179$, see SI 5). Thus our findings do not allow identification of the local source of PHTE from ancient mining since we cannot exclude regional sources (i.e the medieval mines could have been exploited earlier) or even contamination from Spanish Phoenician and Roman mines.

From $\mathrm{AD} 730-950$ to $\mathrm{AD} 1070-1290$ a decline in $\mathrm{Pb}$ and $\mathrm{Sb}$ contamination occurred as shown by a decrease in the $\mathrm{EF}(\mathrm{Pb} \mathrm{EF}=7, \mathrm{Sb}$ $\mathrm{EF}=9), \quad \mathrm{AR} \quad\left(\mathrm{Pb} \quad \mathrm{AR}=0.6 \pm 0.1 \mathrm{mg} \mathrm{m}^{-2} \mathrm{yr}^{-1}, \quad \mathrm{Cu} \quad \mathrm{AR}=0.15\right.$ $\pm 0.02 \mathrm{mg} \mathrm{m}^{-2} \mathrm{yr}^{-1}, \mathrm{Sb} \mathrm{AR}=4.5 \pm 0.7 \mu \mathrm{g} \mathrm{m}^{-2} \mathrm{yr}^{-1}, \mathrm{n}=3$ ) and a shift in isotope composition of $\mathrm{Pb}$ to more radiogenic values $\left({ }^{208} \mathrm{~Pb} /{ }^{206} \mathrm{~Pb}=2.083 \pm 0.002\right.$ and $\left.{ }^{206} \mathrm{~Pb} /{ }^{207} \mathrm{~Pb}=1.185 \pm 0.001\right)$. Lead 


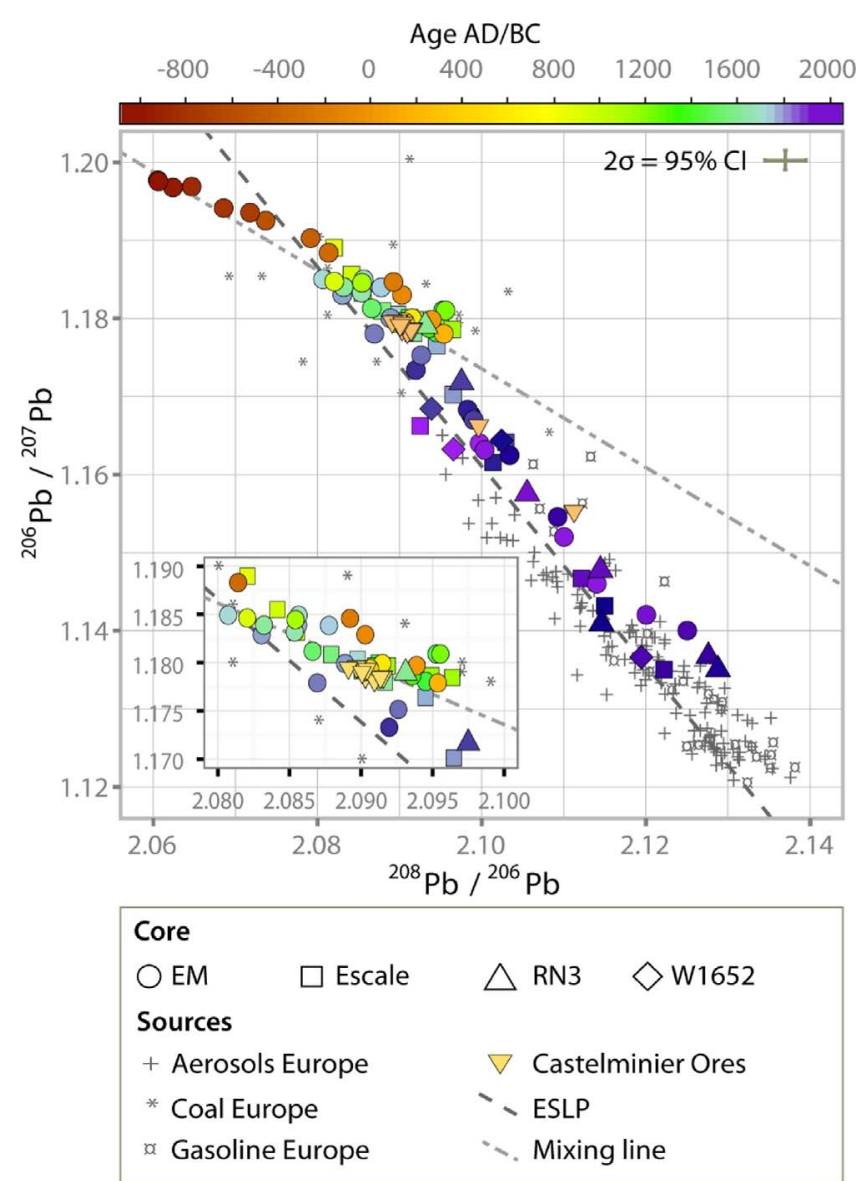

Fig. 4. Lead isotopes ratios of ${ }^{206} \mathrm{~Pb} /{ }^{207} \mathrm{~Pb}$ vs ${ }^{208} \mathrm{~Pb} /{ }^{206} \mathrm{~Pb}$ as measured in the 4 studied cores (circle, square, triangle and diamond for EM, Escale, RN3 and W1652 respectively). Symbols are color coded against the age of each sample with a continuous color scale (top). For comparison, data on ores from the Aulus-les-Bains mining district (downward triangle; See Table S5 in SI) is presented. For comparison with recent lead deposition, European Standard Lead Pollution (ESPL; Haack et al., 2002, 2003) as well as data for Coal, Aerosols and leaded gasoline (Carignan and Gariepy, 1995; Monna et al., 1997; Kober et al., 1999; Véron et al., 1999; Chiaradia and Cupelin, 2000; Díaz-Somoano et al., 2009) is also shown.

and $\mathrm{Sb} \mathrm{AR}$, as well as $\mathrm{Pb}$ isotopic ratios, in the Escale core show comparable values during the same period $(\mathrm{Pb} \mathrm{AR}=0.4 \pm 0.3 ; \mathrm{Sb} \mathrm{AR}=3.0 \pm 1.3$; $\mathrm{n}=6 ; \quad{ }^{206} \mathrm{~Pb} /{ }^{207} \mathrm{~Pb}=1.186 \pm 0.003 ; \quad{ }^{208} \mathrm{~Pb} /{ }^{206} \mathrm{~Pb}=2.084 \pm 0.002 ;$ $\mathrm{n}=3$ ), and although the $\mathrm{Pb}$ contamination is lower, $\mathrm{EF}$ and $\mathrm{AR}$ do not return to initial levels.

Lead contamination during Middle Ages was identified in the EM and the Escale cores by increases in $\mathrm{Pb} \mathrm{EF}$ and $\mathrm{Pb} \mathrm{AR}$, and a shift in $\mathrm{Pb}$ isotopic composition (Figs. 2 and 3). Although the maximum $\mathrm{Pb} \mathrm{EF}$ appears earlier in the Escale core $(\mathrm{Pb} E F=27, \mathrm{AD} 1130-1250)$ than in the $\mathrm{EM}(\mathrm{Pb}$ $\mathrm{EF}=13, \mathrm{AD} 1290-1500$ ), the overall timing of higher $\mathrm{Pb} \mathrm{EF}$ is comparable (i.e. $\mathrm{AD} 1200-\mathrm{AD} 1610$ for the $\mathrm{EM}$ core and $\mathrm{AD} 1130-\mathrm{AD} 1650$ for the Escale one). Contamination is shown to increase continuously since the late Middle Ages in peat cores from Spanish mountains (Martínez Cortizas et al., 2002), Vosges and Alps (Shotyk et al., 1998; Forel et al., 2010) and also at high latitudes as evidenced by lakes sediments (Brännvall et al., 1999) and ice cores (Zheng et al., 2007). Apart from global trends, localized Middle Ages contamination was evident in some mining districts with the example of Black Forest in Germany (Le Roux et al., 2005). $\mathrm{Pb}$ inventories throughout $A D$ 1200-AD 1600 were of $1000-1400 \mathrm{mg} \mathrm{m}^{-2}$ in the Bassiès cores, which is comparable to the Black Forest accumulation but five times higher than in the Swiss Jura (Shotyk et al., 1998). Such increase in EF and $\mathrm{AR}$ in the EM and the Escale cores clearly highlight a local contribution to the $\mathrm{Pb}$ contamination. Moreover, the Middle Ages contamination shows comparable $\mathrm{Pb}$ signatures in the $\mathrm{EM}$ and Escale cores $\left({ }^{206} \mathrm{~Pb} /{ }^{207} \mathrm{~Pb}=1.179 \pm 0.001\right.$ and ${ }^{208} \mathrm{~Pb} /{ }^{206} \mathrm{~Pb}=2.095 \pm 0.001$ in the EM Core, $\mathrm{n}=3 ;{ }^{206} \mathrm{~Pb} /{ }^{207} \mathrm{~Pb}=1.179 \pm 0.001$ and ${ }^{208} \mathrm{~Pb} /{ }^{206} \mathrm{~Pb}=2.093$ \pm 0.002 in the Escale core, $\mathrm{n}=3$ ). The local contribution to this contamination is highlighted by similar isotope ratios in local ores sampled in the district of Aulus-les-Bains and Laquorre mines (Fig. 1; Munoz et al., 2016). Their values ranged from $1.1782 \pm 0.0003$ to 1.1797 \pm 0.0003 for ${ }^{206} \mathrm{~Pb} /{ }^{207} \mathrm{~Pb}$ and $2.089 \pm 0.002$ to $2.092 \pm 0.002$ (with the exception of samples 6 and 7, see Table S5 in SI and Fig. 4). The Aulus-lesBains district is located only $3 \mathrm{~km}$ west of the Bassiès valley and the mining activities there, i.e. maximum mining exploitation and metal production, have been dated to the 14-15th centuries. According to ancient texts, this district is known for being active around $\mathrm{AD} 1320-1340$ and for selling about 40 tons of Silver for coinage (Verna, 1996), thus suggesting a large quantity of metal production and a large ore smelting activity within a short time period. As westerly winds passing over Aulus-les-Bains, and then Bassiès are the major winds in the valley ( $>40 \%$ in frequency over in 2013-2015, see Fig. S4 in SI) this strongly suggests that atmospheric PHTEbearing aerosols, generated by the Aulus-les-Bains mining and metallurgical activities, could have been transported and deposited into the Bassiès catchment.

From about AD 1600 to AD 1950 (Fig. 3) the accumulation of PHTE shows high discrepancies between cores. High AR of 3 PHTE are observed within the $\mathrm{EM}$ core (i.e. $\mathrm{Pb} \mathrm{AR}=12 \pm 3 \mathrm{mg} \mathrm{m}^{-2} \mathrm{yr}^{-1}$; $\mathrm{Sb}$ $\mathrm{AR}=0.07 \pm 0.02 \mathrm{mg} \mathrm{m}^{-2} \mathrm{yr}^{-1} ; \quad \mathrm{Cu} \quad \mathrm{AR}=1.2 \pm 0.2 \mathrm{mg} \mathrm{m}^{-2} \mathrm{yr}^{-1}$, $\mathrm{n}=8$ from $\mathrm{AD} 1740-1860$ to $\mathrm{AD} 1920-1940$ ) and are associated with low EF. On the contrary, the PHTE accumulation in the Escale, W1652A and RN3 cores shows a continuous increase from the 20th century. Accumulation rates were 5-10 fold lower $(\mathrm{Pb}$ $\mathrm{AR}=1.1 \pm 0.5 \mathrm{mg} \mathrm{m}^{-2} \mathrm{yr}^{-1} ; \mathrm{Cu} \mathrm{AR}=0.09 \pm 0.03 \mathrm{mg} \mathrm{m}^{-2} \mathrm{yr}^{-1} ; \mathrm{Sb}$ $\mathrm{AR}=0.01 \pm 0.01 \mathrm{mg} \mathrm{m}^{-2} \mathrm{yr}^{-1}, \mathrm{n}=4$ from $\mathrm{AD} 1650-1680$ to $\mathrm{AD}$ 1870-1920) during the 19th century followed by a continuous increase of $\mathrm{AR}$ and $\mathrm{EF}$. The increase in $\mathrm{Pb}$ and $\mathrm{Sb}$ deposition observed in the Escale core is consistent with increases observed in other cores across Europe, which were linked to an onset of contamination related to industrialization (Shotyk et al., 1996; Cloy et al., 2005).

The recent overall $\mathrm{Pb} \mathrm{AR}$ and $\mathrm{EF}$ trends are similar, decreasing (by a factor 10) from the 1960-1990s to the present day in the four cores. By comparison, $\mathrm{Cu} \mathrm{AR}$ and $\mathrm{EF}$ shows a continuous increasing trend. This is in agreement with trends observed at French and European scale in moss surveys (Harmens et al., 2010, 2015) as well as other recent peat accumulation records across Europe (Cloy et al., 2009; Olid et al., 2010). Overall, PHTE inventories were low compared to reported European values (Rausch et al., 2005; Olid et al., 2010; See Table S1 in SI). These findings suggest a distal recent contribution of PHTE deposition onto Bassiès peatlands, which is further supported by the $\mathrm{Pb}$ isotopic ratios shift to non-radiogenic values $\left({ }^{20} \mathrm{~Pb} /{ }^{207} \mathrm{~Pb}=1.137 \pm 0.002 ;{ }^{208} \mathrm{~Pb} /{ }^{206} \mathrm{~Pb}\right.$ $=2.124 \pm 0.004)$ around $\mathrm{AD} 1960-1990$ before shifting to more radiogenic values in the surface samples (i.e. $\mathrm{AD}$ 2010-2012; $\left.{ }^{206} \mathrm{~Pb} /{ }^{207} \mathrm{~Pb}=1.165 \pm 0.002 ; \quad{ }^{208} \mathrm{~Pb} /{ }^{206} \mathrm{~Pb}=2.098 \pm 0.004, \quad \mathrm{n}=4\right)$. The contribution of global contamination due to the widespread industrialization and the use of leaded gasoline is supported by the agreement between isotopic ratios in our samples and the ESLP (European Standard Lead Pollution; Haack et al., 2002, 2003). By comparing the isotopic ratios of aerosols and leaded gasoline, our isotopic ratios show a mix between leaded gasoline and other industrial sources with the highest contribution of leaded gasoline occurring throughout 1960-1990 (Monna et al., 1997; Véron et al., 1999; Bollhöfer and Rosman, 2001; See Fig. 4).

\subsection{Variability of the accumulation in time and space}

Total inventories of $\mathrm{Pb}$ and $\mathrm{Sb}$ for the period 1950-2015 (Table 1) follow a decreasing trend between the cores in the order of W1652> EM > Escale > RN3, with less than a two-fold difference between highest and lowest inventories. Bindler et al. (2004) showed that a factor up to 2 could be found between cores within the same peatland due to within site variability in peat characteristics (Bindler et al., 2004; 


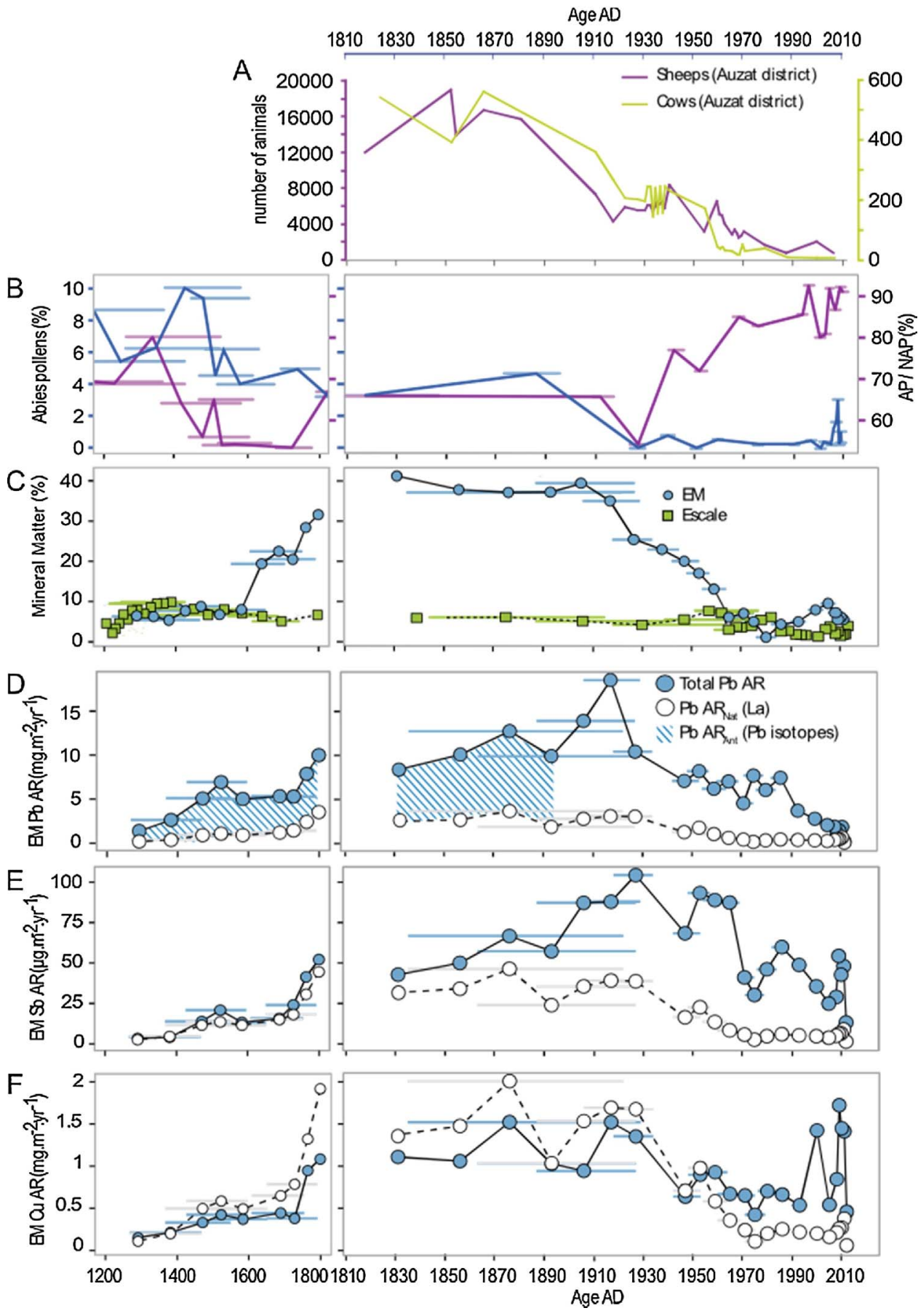

Fig. 5. Recent changes in Bassiès valley, A) Evolution of grazing pressure in the Auzat commune from agricultural statistics, B) Abies pollens (\%) and AP/NAP (Arboreal Pollen grains/Non-Arboreal Pollen grains in\%) from the Orry de Theo mire C) Mineral Matter content (\%) from 2 of the Bassiès cores (i.e. EM and Escale) D) E) and F) Total AR, Estimated Natural AR in the EM core (from PHTE/La ratio in the Bassiès Granite and EM core deep samples) of $\mathrm{Sb}$, $\mathrm{Cu}$ and $\mathrm{Pb}$ and Estimated anthropogenic $\mathrm{Pb}$ (from isotope ratios). Horizontal bars represent the 95\% confidence interval from CLAM age-depth models, left column shows changes over the period 1200-1800 CE, wheras the right column shows the period 1810-2010 CE at a higher resolution.
Hansson et al., 2013). Yet, for the Escale and the EM core, PHTE accumulations were also comparable throughout AD 1000-1600. A study on $\mathrm{Pb}$ and $\mathrm{Ti}$ accumulation in Sphagnum shows that even a higher variability between AR could be observed between samples from the same site (i.e. 5.6-7.8 $\times$ ) due to a difference in Sphagnum production rates (Kempter et al., 2010). The variation in accumulation between the 4 studied cores may therefore be interpreted as a difference in the uptake of PHTE, connected to either peat characteristics and/or potential fluvial input, rather than differences in atmospheric deposition. $\mathrm{Cu}$ inventories from 1950 in RN3 core were approximately twice as high as in the others cores. There was also a factor of $\sim 2$ between the minimum and maximum total inventories but appearing in the order RN3 $>$ W1652 > EM3 > Escale. The order was the same as for $\mathrm{Pb}$ and
Sb inventories except that RN3 had higher inventories rather than the lowest. These inventories associated with higher $\mathrm{Cu}$ EF in RN3 core suggest that a specific unidentified process is involved in the $\mathrm{Cu}$ accumulation, possibly connected to localization as RN3 was the only core on a ridge, $300 \mathrm{~m}$ above the others. Enhanced deposition of aerosols due to orographic enhancement is documented (Weathers et al., 2000; Likuku, 2006) but there is no reason for $\mathrm{Cu}$ to be the only element concerned by this process, thus $\mathrm{Cu}$ AR should be interpreted carefully. It is therefore clear that PHTE accumulation in mountain environments needs further investigations in order to fully understand the local, regional and atmospheric parameters that influence the hotspots of PHTE accumulation in these diverse landscapes (Le Roux et al., 2016). 


\subsection{Influence of mineral matter on the accumulation of PHTE in the EM} core

During the last 5 centuries, the EM core mineral matter content was above $10 \%$, (i.e. $\mathrm{AD} 1580-1730$ to $1949-1958$, Fig. 5) with a peak at up to $40 \%$ (AD 1770-1890). PHTE inventories therefore differ greatly between the EM and Escale peat records (i.e. by a factor 10, Table 1). It is not likely that this amount of PHTE was delivered by atmospheric deposition; i.e. atmospherically deposited on the EM peatland but not on the Escale located $500 \mathrm{~m}$ eastwards, hence we suggest that fluvial derived erosion of the surrounding soils is responsible for such high lithogenic amounts in the EM mire.

Rocks and soils contain trace amount of PHTEs included in their minerals. High amount of mineral matter deposition to peatlands could lead to accumulation of natural PHTE. In Fig. 5, natural AR of PHTE to the EM core has been estimated based on the PHTE ratios to La in the two oldest samples of the EM core, calculated by using the equation (Eq. (3)) below:

$\operatorname{PHTEAR}_{(\text {litho })}=\frac{P H T E}{L a_{(l i t h o)}} \times L a A R$

Using this equation, the estimated lithogenic Sb AR were in good agreement with total Sb AR (calculated using Eq. (2) except throughout periods of Sb contamination; i.e. $250 \mathrm{BC}$ - AD 20 to 380-560 AD and AD $1660-1800$ to 1770-1890; see Fig. 5). Total AR began to increase from estimated lithogenic Sb AR around AD 1770 - 1890 in the EM core, which corresponds to recent Sb contamination in the Escale core (e.g. AD 1830-1910). Estimated lithogenic Cu AR trends were comparable with total $\mathrm{Cu} \mathrm{AR}$ although they were consistently higher by a factor 1.2-1.5 $\left(\mathrm{R}^{2}=0.63, \mathrm{p}<0.05, \mathrm{n}=17\right)$, until the recent increase in $\mathrm{Cu}$ contamination. This suggests that mineral deposition to the EM mire, either fluvial or aeolian, has led to a greater accumulation of "natural" PHTE, explaining the differences in the accumulation of $\mathrm{Cu}$ and $\mathrm{Sb}$ between the Escale and the EM cores. $\mathrm{Pb}$ estimated lithogenic contribution were in good agreement with total $\mathrm{Pb}$ AR before the Antiquity contamination as well as between the Antiquity and the medieval contamination. However, our result show $\mathrm{Pb}$ AR which are 5 to 10 fold lower than the total $\mathrm{Pb}$ AR during the erosive period. This demonstrates that another source has contributed to the $\mathrm{Pb}$ accumulation from AD 1580-1730 to 1949-1958 in the EM peatland. Inventories of Anthropogenic PHTE have therefore been calculated and are reported in Table 1 . About $600 \mathrm{mg} \mathrm{m}^{-2}$ of $\mathrm{Pb}, 300 \mathrm{mg} \mathrm{m}^{-2}$ of $\mathrm{Cu}$ and $10 \mathrm{mg} \mathrm{m}^{-2}$ of Sb were directly linked to erosive deposition of lithogenic PHTE from the surrounding soils throughout AD 1600 to AD 1950. These high contributions of lithogenic PHTE to the total inventories (i.e. $62 \%$ for $\mathrm{Sb}$ and $100 \%$ for $\mathrm{Cu}$ ) highlight the influence of detrital mineral matter to the high accumulation of PHTE in peatlands.

\subsection{Remobilization of ancient stored $\mathrm{Pb}$}

Organic soil erosion has been shown to be a source of stored contaminants (i.e. $\mathrm{Pb}$ ) to lakes in Bassiès valley (Bacardit et al., 2012), especially $\mathrm{Pb}$ stored from leaded gasoline contamination over the last century, contributing to contamination up to present time (Bacardit and Camarero, 2010). From the Middle Ages to AD 1900 - 1930, the Pb isotope ratios in the EM core were aligned between two end-members that were the signature of Aulus-les-Bains mining district ores and the signature of the bottom of the EM core used as the natural reference (Fig. 4). It supports our conclusion that the high amount of $\mathrm{Pb}$ accumulated in the peat is a mix between these two sources. We used the ${ }^{206} \mathrm{~Pb} /{ }^{207} \mathrm{~Pb}$ ratio in the bottom of EM core and Aulus-les-Bains ores mean ratios to calculate anthropogenic $\left(\mathrm{Pb} \mathrm{AR}_{\mathrm{Ant}}\right)$ and natural contributions to $\mathrm{Pb}$ accumulation using the equation (Eq. (4)) below (the $\mathrm{Pb} \mathrm{AR}$ Ant is reported in Fig. 5):
$P b A R_{\text {Ant. }}=P b *\left(\frac{{ }^{206} \mathrm{~Pb} /{ }^{207} \mathrm{P} b_{\text {Sample }}-{ }^{206} \mathrm{~Pb} /{ }^{207} \mathrm{~Pb} b_{\text {Nat. }}}{{ }^{206} \mathrm{~Pb} /{ }^{207} \mathrm{P} b_{\text {Sample }}-{ }^{206} \mathrm{~Pb} /{ }^{207} \mathrm{~Pb} \text { Ant. }}\right)$

Estimated anthropogenic contributions (i.e. Pb from the Aulus-lesBains ores) range from 83 to $100 \%$ throughout $\mathrm{AD} 1200-1600$ and 64-84\% from AD 1580-1730 to AD 1920-1936. This timing is synchronous with the erosive supply to the EM core and corresponds to a period of very low atmospheric contamination in the Escale core. It suggests that $\mathrm{Pb}$ from Aulus-les-Bains atmospheric contamination (i.e. AD 1200-1600), stored in surrounding soils, was remobilized by erosive processes to the EM mire at the same time as the lithogenic PHTE. Moreover, the difference between total $\mathrm{Pb} \mathrm{AR}$ and $\mathrm{Pb} \mathrm{AR}_{\mathrm{Ant}}$ is in good agreement with the estimation of natural $\mathrm{Pb}$ from background $\mathrm{Pb} / \mathrm{La}$ $\left(\mathrm{r}^{2}=0.92, \mathrm{p}<0.05, \mathrm{n}=11\right)$. It justifies the use of EM background isotopic ratios and $\mathrm{Pb} / \mathrm{La}$ Ratio for the estimation. The contribution of Aulus-les-Bains mining district $\mathrm{Pb}$ to total $\mathrm{Pb}$ AR from AD 1900-1930 to AD 1950-1960 could not be deducted as the isotopic ratios were no longer aligned between the two end members. However, the beginning of the shift from the mixing line fits with the onset of atmospheric $\mathrm{Pb}$ contamination found in the other records of Bassiès valley (i.e the beginning of the 20th century).

The total $\mathrm{Pb}$ inventories and the overall timing of Aulus-les-Bains mining district contamination were comparable between the Escale and $\mathrm{EM}$ core from $\mathrm{AD} 1200$ to 1600 . Considering that $\mathrm{Pb}$ atmospheric contamination from Aulus-les-Bains mining district did not occur after AD 1600 (as observed in the Escale core) we could estimate the inventory of remobilized $\mathrm{Pb}$ in $\mathrm{EM}$ up to $\mathrm{AD} 1880$ - 1920. The results show that a total of $2400 \mathrm{mg} \mathrm{m}^{2}$ of $\mathrm{Pb}$ were supplied to the mire by erosive processes with $1800 \mathrm{mg} \mathrm{m}^{-2}$ of remobilized anthropogenic $\mathrm{Pb}$. Even if the remobilized $\mathrm{Pb}$ was not estimated after AD 1880-1920, the amount of remobilized $\mathrm{Pb}$ was about one third of the total $\mathrm{Pb}$ inventory in $\mathrm{EM}$ core $\left(\mathrm{Pb} \mathrm{Inv}=6300 \mathrm{mg} \mathrm{m}^{-2}\right)$ highlighting the importance of soil remobilization in PHTE accumulation

\subsection{Importance of ancient atmospheric contamination onto PHTE accumulation}

To show the importance of ancient anthropogenic contamination (i.e. $\mathrm{AD} 1800$ and the first contamination around $500 \mathrm{BC}$ ), the pre-industrial contribution to the total anthropogenic PHTE inventories were estimated. Anthropogenic inventories were calculated by subtracting natural inventories following Eq. (3). An approximation can be made coupling the anthropogenic inventories in the Escale core after AD 1000 (as remobilization occurred in the EM core) to the EM core prior to $\mathrm{AD}$ 1000. Estimated anthropogenic atmospheric accumulations prior to $\mathrm{AD}$ 1800 were about $85 \%$ for $\mathrm{Pb}, 60 \%$ for $\mathrm{Sb}$ and $69 \%$ for $\mathrm{Cu}$. Contamination of $\mathrm{Sb}$ and $\mathrm{Pb}$ after $\mathrm{AD} 1800$ is lower than other European records, suggesting that the Bassiès valley was recently nearly isolated from atmospheric contamination. On the contrary, Middle Ages contamination (for $\mathrm{Pb}$ only) and Antiquity contamination appears to be higher than in other European records. It underlines the importance of past mining activities to the PHTE deposition and inventories over time, even in such isolated valleys. Such high pre-industrial contributions to the total PHTE accumulation are found elsewhere in mountain environment with variable contributions (i.e. 30 to $78 \%$ for Sb and 30 to $65 \%$ for $\mathrm{Pb}$; see Table 1 and references therein) with the lowest contributions for places like Swiss Jura that are more isolated from local sources of contamination. These findings highlight the variability of accumulation histories in mountain environments and the close relationship between local activities and PHTE accumulations.

\subsection{Linking local history to PHTE remobilization}

The Bassiès valley was impacted by intensifying grazing activities from the late Neolithic to the 1960s, compared to only low pressure from grazing at present times. Erosive processes have been linked to 
sheep and cows grazing in Orry de Theo mire (close to the EM bog, Fig. 1) from AD 1800 to AD 1960 (Galop et al., 2011). During the 19th century, cattle and sheep livestock with up to 500 and 20000 animals respectively were reported for the Auzat district (in which Bassiès valley is one of the high altitude pastures). These livestock were responsible for intense soil erosion that was eventually reduced by the abandonment of intense agro-pastoral activities in the 1960s. This also led to a reforestation of the Bassiès valley by trees (Betula, Pinus) and shrubs (Juniperus, Calluna; Galop et al., 2011). Intense erosion to Etang Mort as recorded in the EM core (i.e. mineral matter content up to $40 \%$; Fig. 5) shows a positive relationship with both the intense grazing activities and the decrease in erosion from the 1950's when a change in agro-pastoral practices occurred. The maximum intensity of forest clearing is highlighted by a minimum ratio between Non-Arboreal pollen grains (NAP) and Arboreal-pollens grains (AP) (55-65\% from AD $1470-1610$ to 1920-1930) which is consistent with decreased presence of pollens from high altitude arboreal vegetation such as Abies trees (4-5\%). The timing of increased erosion and remobilization of $\mathrm{Pb}$ is consistent with the coevolution in the Orry de Theo bog. Agro pastoral practices have induced intense erosion leading to lithogenic PHTE accumulation (especially for $\mathrm{Sb}$ and $\mathrm{Cu}$ ) but also to a remobilization of $\mathrm{Pb}$ stored in surrounding soils.

\section{Conclusions}

Our results presented here clearly emphasize that human activities in the surroundings of Bassiès valley had a great influence on the accumulation of PHTEs in the watershed. Local ancient anthropogenic activities (i.e. Middle Ages) have dispersed PHTE (especially $\mathrm{Pb}$ ) through the atmosphere by mining and metallurgy, and enhanced the terrestrial dispersion of natural and previously stored PHTE by intensive agro-sylvo-pastoral activities. This remobilization of PHTE represented a large portion of the total PHTE inventory, suggesting that terrestrial transfers were important and acting as hotspots of accumulated contaminants to downstream mires many years after the atmospheric contamination occurred. This clearly show the long legacy of human-environment interaction and that human activities have impacted the surrounding environment on centennial to millennial scales.

\section{Funding}

This research has been supported by generous grants to Gaël Le Roux from LABEX DRIIHM ANR (Agence National Recherche) - OHM haut Vicdessos, ADEME (Agence De l'Eau et de la Maitrise de l'Energie) and ANR JCJC TRAM (ANR-15-CE01-0008). Sophia Hansson is an AXA Research Fund fellow (14-AXA-PDOC-030) with further support from PRESTIGE/Marie Curie Action COFUND (PRESTIGE-2014-1-0037). Additional ${ }^{14} \mathrm{C}$ analyses by LMC14 on ARTEMIS national instrument, funded by INSU, are acknowledged. Funding from the ANR MODE RESPYR (ANR 2010 JCJC 1804 01) is also aknowledged.

\section{Acknowledgements}

The authors wish to thank Fabrice Monna (University of Dijon, France) and Antonio Martínez-Cortizas (University of Santiago de Compostella, Spain) for sharing of samples (Vosges) and data (Galicia), Marie-José Tavella \& Alicia Cuvier (both EcoLab), Frederic Candaudap \& Aurélie Lanzanova (both ICP-MS platform-OMP) and David Baqué (ICP-OES platforme PLANET, EcoLab) for helping us with the preparation and analyses of samples. We thank also Florian Téreygeol for his sampling of ores during the Castel Minier excavations in Aulus les Bains mining district (Projet Collectif de Recherches; "Le Castel Minier, Aulus les Bains, Ariège, France" funded by Ministère de la Culture, France). The GET laboratory is thanked for its analytical support (TIMS and clean room facilities).

\section{Appendix A. Supplementary data}

Supplementary data associated with this article can be found, in the online version, at http://dx.doi.org/10.1016/j.ancene.2017.09.002.

\section{References}

Appleby, P.G., 2002. Chronostratigraphic techniques in recent sediments. In tracking environmental change using lake sediments. In: Last, W.M., Smol, J.P. (Eds.), Developments in Paleoenvironmental Research. Springer, Netherlands, pp. 171-203.

Bacardit, M., Camarero, L., 2010. Modelling Pb, Zn and As transfer from terrestrial to aquatic ecosystems during the ice-free season in three Pyrenean catchments. Sci. Total Environ. 408 (23), 5854-5861.

Bacardit, M., Krachler, M., Camarero, L., 2012. Whole-catchment inventories of trace metals in soils and sediments in mountain lake catchments in the Central Pyrenees: apportioning the anthropogenic and natural contributions. Geochim. Cosmochim. Acta 82, 52-67.

Bindler, R., Klarqvist, M., Klaminder, J., Förster, J., 2004. Does within-bog spatial variability of mercury and lead constrain reconstructions of absolute deposition rates from single peat records? The example of Store Mosse, Sweden.G lob. Biogeochem. Cycles 18 (3), GB3020.

Bindler, R., Segerstrom, U., Pettersson-Jensen, I.M., Berg, A., Hansson, S., Holmstrom, H., Olsson, K., Renberg, I., 2011. Early medieval origins of iron mining and settlement in central Sweden: multiproxy analysis of sediment and peat records from the Norberg mining district. J. Archaeolog. Sci. 38 (2), 291-300.

Binford, M.W., 1990. Calculation and uncertainty analysis of ${ }^{210} \mathrm{~Pb}$ dates for PIRLA project lake sediment cores. J. Paleolimnol. 3 (3), 253-267.

Blaauw, M., 2010. Methods and code for classical age-modelling of radiocarbon sequences. Quat. Geochronol 5 (5), 512-518.

Bollhöfer, A., Rosman, K.J.R., 2001. Lead isotopic ratios in European atmospheric aerosols. Phys. Chem. Earth Part B Hydrol. Oceans Atmos. 26 (10), 835-838.

Brännvall, M.-L., Bindler, R., Renberg, I., Emteryd, O., Bartnicki, J., Billström, K., 1999. The medieval metal industry was the cradle of modern large-Scale atmospheric lead pollution in northern europe. Environ. Sci. Technol. 33 (24), 4391-4395.

Camarero, L., Masqué, P., Devos, W., Ani-Ragolta, I., Catalan, J., Moor, H.C., Pla, S., Sanchez-Cabeza, J.A., 1998. Historical variations in lead fluxes in the pyrenees (Northeast Spain) from a dated lake sediment core. Water Air Soil Pollut. 105 (1-2), 439-449.

Camizuli, E., Monna, F., Scheifler, R., Amiotte-Suchet, P., Losno, R., Beis, P., Bohard, B., Chateau, C., Alibert, P., 2014. Impact of trace metals from past mining on the aquatic ecosystem: a multi-proxy approach in the Morvan (France). Environ. Res. 134, 410-419.

Carignan, J., Gariepy, C., 1995. Isotopic composition of epiphytic lichens as a tracer of the sources of atmospheric lead emissions in southern Quebec, Canada.G eochim. Cosmochim. Acta 59, 4427-4433.

Chiaradia, M., Cupelin, F., 2000. Behaviour of airborne lead and temporal variations of its source effects in Geneva (Switzerland): comparison of anthropogenic versus natural processes. Atmos. Environ. 34 (6), 959-971.

Cloy, J.M., Farmer, J.G., Graham, M.C., MacKenzie, A.B., Cook, G.T., 2005. A comparison of antimony and lead profiles over thepast 2500 years in Flanders Moss ombrotrophic peat bog, Scotland. J. Environ. Monit. 7 (12), 1137-1147.

Cloy, J.M., Farmer, J.G., Graham, M.C., MacKenzie, A.B., 2009. Retention of as and sb in ombrotrophic peat bogs: records of $\mathrm{As}, \mathrm{Sb}$, and $\mathrm{Pb}$ deposition at four scottish sites. Environ. Sci. Technol. 43 (6), 1756-1762.

Díaz-Somoano, M., Kylander, M.E., López-Antón, M.A., Suárez-Ruiz, I., MartínezTarazona, M.R., Ferrat, M., Kober, B., Weiss, D.J., 2009. Stable lead isotope compositions in selected coals from around the world and implications for present day aerosol source tracing. Environ. Sci. Technol. 43 (4), 1078-1085.

De Vleeschouwer, F., Vanneste, H., Mauquoy, D., Piotrowska, N., Torrejón, F., Roland, T., Stein, A., Le Roux, G., 2014. Emissions from pre-Hispanic metallurgy in the south american atmosphere. PLoS One 9 (10), e111315.

Dubois, C., 1999. Les mines de plomb argentifère et zinc d'Aulus-les-Bains (Ariège). Archéol. Midi. Médiév. 17 (1), 187-211.

Forel, B., Monna, F., Petit, C., Bruguier, O., Losno, R., Fluck, P., Begeot, C., Richard, H., Bichet, V., Chateau, C., 2010. Historical mining and smelting in the Vosges Mountains (France) recorded in two ombrotrophic peat bogs. J. Geochem. Explor 107, 9-20.

Galop, D., 1998. La forêt l'homme et le troupeau dans les Pyrénées. 6000 ans d'histoire de l'environnement entre Garonne et Méditerranée. GEODE, Laboratoire d'Ecologie Terrestre et FRAMESPA edts, Toulouse, pp. 1-303.

Galop, D., Jalut, G., 1994. Differential human impact and vegetation history in two adjacent Pyrenean valleys in the Ariège basin, southern France, from 3000 B.P. to the present. Veg. Hist. Archaeobot. 3 (4), 225-244.

Galop, D., Houet, T., Mazier, F., Leroux, G., Rius, D., 2011. Grazing activities and biodiversity history in the Pyrénées - the use of paleoecology and historical ecology to provide new insights on high-altitude ecosystems in the framework of a Human Environment Observatory. Pages News 19 (2), 53-55.

Galop, D., Rius, D., Cugny, C., Mazier, F., 2013. A history of long-term human-environment interactions in the french Pyrenees inferred from the pollen data. Continuity and Change in Cultural Adaptation to Mountain Environments. Springer, New York, pp. 19-30.

Givelet, N., Le Roux, G., Cheburkin, A., Chen, B., Frank, J., Goodsite, M.E., Kempter, H., Krachler, M., Noernberg, T., Rausch, N., Rheinberger, S., Roos-Barraclough, F., Sapkota, A., Scholz, C., Shotyk, W., 2004. Suggested protocol for collecting: handling and preparing peat cores and peat samples for physical, chemical, mineralogical and 
isotopic analyses. J. Environ. Monit. JEM 6 (5), 481-492.

Haack, U.K., Gutsche, F.H., Plessow, K., Heinrichs, H., 2002. On the isotopic composition of $\mathrm{Pb}$ in cloud waters in central Germany. a source discrimination study. Water Air Soil Pollut. 139 (1-4), 261-288.

Haack, U.K., Heinrichs, H., Gutsche, F.H., Plessow, K., 2003. The isotopic composition of anthropogenic $\mathrm{pb}$ in soil profiles of northern Germany: evidence for pollutant $\mathrm{Pb}$ from a continent-wide mixing system. Water Air Soil Pollut. 150 (1-4), 113-134.

Hansson, S.V., Rydberg, J., Kylander, M., Gallagher, K., Bindler, R., 2013. Evaluating paleoproxies for peat decomposition and their relationship to peat geochemistry. Holocene 23 1666-1167.

Hansson, S.V., Bindler, R., De Vleeschouwer, F., 2015. Environmental contaminants, developments in paleoenvironmental research. Using Natural Archives to Track Sources and Long-term Trends of Pollution Ch. 12 Vol. 18. Springer, pp. 323-354.

Harmens, H., Norris, D.A., Steinnes, E., Kubin, E., Piispanen, J., Alber, R., Aleksiayenak, Y., Blum, O., Coşkun, M., Dam, M., et al., 2010. Mosses as biomonitors of atmospheric heavy metal deposition: spatial patterns and temporal trends in Europe. Environ. Pollut. 158 (10), 3144-3156.

Harmens, H., Norris, D.A., Sharps, K., Mills, G., Alber, R., Aleksiayenak, Y., Blum, O., Cucu-Man, S.-M., Dam, M., De Temmerman, L., et al., 2015. Heavy metal and nitrogen concentrations in mosses are declining across Europe whilst some hotspots remain in 2010. Environ. Pollut. 200, 93-104.

Hong, S.M., Candelone, J.P., Patterson, C.C., Boutron, C.F., 1994. Greenland ice evidence of hemispheric lead pollution 2 millebbia ago by Greek and Roman civilizations. Science 265, 1841-1843.

Küttner, A., Mighall, T.M., De Vleeschouwer, F., Mauquoy, D., Martínez Cortizas, A., Foster, I.D.L., Krupp, E., 2014. A 3300-year atmospheric metal contamination record from Raeburn Flow raised bog, south west Scotland. J. Archaeol Sci. 44, 1-11.

Karlsson, J., Segerström, U., Berg, A., Mattielli, N., Bindler, R., 2015. Tracing modern environmental conditions to their roots in early mining, metallurgy, and settlement in Gladhammar, southeast Sweden: vegetation and pollution history outside the traditional Bergslagen mining region. Holocene 25 (6), 944-955.

Kaste, J.M., Friedland, A.J., Stürup, S., 2003. Using stable and radioactive isotopes to trace atmospherically deposited $\mathrm{Pb}$ in montane forest soils. Environ. Sci. Technol. 37 (16), 3560-3567.

Kempter, H., Krachler, M., Shotyk, W., 2010. Atmospheric Pb and Ti accumulation rates from sphagnum moss: dependence upon plant productivity. Environ. Sci. Amp. Technol. 44 (14), 5509-5515.

Klaminder, J., Renberg, I., Bindler, R., Emteryd, O., 2003. Isotopic trends and background fluxes of atmospheric lead in northern Europe: analyses of three ombrotrophic bogs from south Sweden. Glob. Biogeochem. Cycles 17 (1), 1019.

Kober, B., Wessels, M., Bollhöfer, A., Mangini, A., 1999. Pb isotopes in sediments of Lake Constance: central Europe constrain the heavy metal pathways and the pollution history of the catchment, the lake and the regional atmosphere. Geochim. Cosmochim. Acta 63 (9), 1293-1303.

Krachler, M., Le Roux, G., Kober, B., Shotyk, W., 2004. Optimising accuracy and precision of lead isotope measurement (206Pb: 207Pb, 208Pb) in acid digests of peat with ICPSMS using individual mass discrimination correction. J. Anal. At. Spectrom. 19 (3), 354-361.

Kylander, M.E., Weiss, D.J., Martínez Cortízas, A., Spiro, B., Garcia-Sanchez, R., Coles, B.J., 2005. Refining the pre-industrial atmospheric $\mathrm{Pb}$ isotope evolution curve in Europe using an 8000 year old peat core from NW Spain. Earth Planet Sci. Lett. 240 (2), 467-485

Le Roux, G., De Vleeschouwer, F., 2010. Preparation of peat samples for inorganic geochemistry used as palaeoenvironmental proxies. Mires Peat 7 (4), 1-9.

Le Roux, G., Aubert, D., Stille, P., Krachler, M., Kober, B., Cheburkin, A., Bonani, G., Shotyk, W., 2005.. Recent atmospheric Pb deposition at a rural site in southern Germany assessed using a peat core and snowpack, and comparison with other archives. Atmos. Environ. 39, 6790-6801.

Le Roux, G., Duffa, C., Vray, F., Renaud, P., 2010. Deposition of artificial radionuclides from atmospheric Nuclear Weapon Tests estimated by soil inventories in French areas low-impacted by Chernobyl. J. Environ. Radioact. 101, 211-218.

Le Roux, G., Hansson, S.V., Claustres, A., 2016. In: In: Gregory, B.G., Shroder, J.F. (Eds.), Chapter 3 - Inorganic Chemistry in the Mountain Critical Zone: Are the Mountain Water Towers of Contemporary Society Under Threat by Trace Contaminants? Developments in Earth Surface Processes Vol. 21. Elsevier, pp. 131-154.

Likuku, A.S., 2006. Wet deposition of ${ }^{210} \mathrm{~Pb}$ aerosols over two areas of contrasting topography. Environ. Res. Lett. 1 (1), 014007.

Martínez Cortizas, A., García-Rodeja, E., Pontevedra Pombal, X., Nóvoa Muñoz, J.C., Weiss, D., Cheburkin, A., 2002. Atmospheric Pb deposition in Spain during the last 4600 years recorded by two ombrotrophic peat bogs and implications for the use of peat as archive. Sci. Total Environ. 292 (1-2), 33-44.

Mauquoy, D., Geel van, B., Blaauw, M., Speranza, A., Plicht van der, J., 2004. Changes in solar activity and Holocene climatic shifts derived from 14C wiggle-match dated peat deposits. Holocene 14 (1), 45-52.

Monna, F., Lancelot, J., Croudace, I.W., Cundy, A.B., Lewis, J.T., 1997. Pb isotopic composition of airborne particulate material from France and the southern United Kingdom: Implications for $\mathrm{Pb}$ pollution sources in urban areas. Environ. Sci. Technol. 31 (8), 2277-2286

Monna, F., Galop, D., Carozza, L., Tual, M., Beyrie, A., Marembert, F., Chateau, C., Dominik, J., Grousset, F., 2004a. Environmental impact of early Basque mining and smelting recorded in a high ash minerogenic peat deposit. Sci. Total Environ. 327 (13), 197-214.

Monna, F., Petit, C., Guillaumet, J.P., Jouffroy-Bapicot, I., Blanchot, C., Dominik, J., Losno, R., Richard, H., Lévêque, J., Chateau, C., 2004b. History and environmental impact of mining activity in Celtic Aeduan territory recorded in a peat bog (Morvan, France). Environ. Sci. Technol. 38 (3), 665-673.

Monna, F., Camizuli, E., Revelli, P., Biville, C., Thomas, C., Losno, R., Scheifler, R., Bruguier, O., Baron, S., Chateau, C., Ploquin, A., Alibert, P., 2011. Wild brown trout affected by historical mining in the cevennes national park, France. Environ. Sci. Technol. 45, 6823-6830.

Munoz, M., Baron, S., Boucher, A., Salvi, S., Beziat, D., 2016. Mesozoic vein-type Pb-Zn mineralization in the Pyrenees: lead isotopic and fluid inclusion evidence from the Les Argentières and Laquorre deposits. Compt. Rendus Geosci. 348, 322-332.

Olid, C., Garcia-Orellana, J., Martínez-Cortizas, A., Masqué, P., Peiteado-Varela, E., Sanchez-Cabeza, J.-A., 2010. Multiple site study of recent atmospheric metal (Pb: zn and $\mathrm{Cu}$ ) deposition in the NW Iberian Peninsula using peat cores. Sci. Total Environ. 408 (22), 5540-5549.

Paris, J.R., King, R.A., Stevens, J.R., 2015. Human mining activity across the ages determines the genetic structure of modern brown trout (Salmo trutta L.) populations. Evol. Appl. 8 (6), 573-585.

Plant, J.A., Klaver, G., Locutura, J., Salminen, R., Vrana, K., Fordyce, F.M., 1997. The forum of european geological surveys geochemistry task group inventory 1994-1996. J. Geochem. Explor 59 (2), 123-146.

Py-Saragaglia, V., Cunill Artigas, R., Métailié, J.-P., Ancel, B., Baron, S., ParadisGrenouillet, S., Lerigoleur, E., Badache, N., Barcet, H., Galop, D, 2017. Late Holocene history of woodland dynamics and wood use in an ancient mining area of the Pyrenees (Ariège, France). Quat. Int. s1. http://dx.doi.org/10.1016/j.quaint.2017. 01.012.

Rausch, N., Nieminen, T., Ukonmaanaho, L., Le Roux, G., Krachler, M., Cheburkin, A.K., Bonani, G., Shotyk, W., 2005. Comparison of atmospheric deposition of copper: nickel, cobalt, zinc, and cadmium recorded by finnish peat cores with monitoring data and emission records. Environ. Sci. Technol. 39 (16), 5989-5998.

Renberg, I., Persson, M.W., Emteryd, O., 1994. Pre-industrial atmospheric lead contamination detected in Swedish lake sediments. Nature 368 (6469), 323-326.

Rosman, K.J.R., Chisholm, W., Hong, S., Candelone, J.-P., Boutron, C.F., 1997. Lead from carthaginian and roman spanish mines isotopically identified in Greenland ice dated from 600 B. C. to 300 A. d. Environ. Sci. Technol. 31 (12), 3413-3416.

Sen, I.S., Peucker-Ehrenbrink, B., 2012. Anthropogenic disturbance of element cycles at the earth's surface. Environ. Sci. Technol. 46 (16), 8601-8609.

Shotyk, W., Cheburkin, A.K., Appleby, P.G., Fankhauser, A., Kramers, J.D., 1996. Two thousand years of atmospheric arsenic, antimony, and lead deposition recorded in an ombrotrophic peat bog profile, Jura Mountains, Switzerland. Earth Planet Sci. Lett. 145 (1-4), E1-E7.

Shotyk, W., Weiss, D., Appleby, P.G., Cheburkin, A.K., Frei, R., Gloor, M., Kramers, J.D., Reese, S., Van der Knaap, W.O., 1998. History of atmospheric lead deposition since 12,370 C-14 yr BP from a peat bog, Jura Mountains, Switzerland. Science 281, 1635-1640.

Stankwitz, C., Kaste, J.M., Friedland, A.J., 2012. Threshold increases in soil lead and mercury from tropospheric deposition across an elevational gradient. Environ. Sci. Technol 46 (15), 8061-8068.

Véron, A., Flament, P., Bertho, M.L., Alleman, L., Flegal, R., Hamelin, B., 1999. Isotopic evidence of pollutant lead sources in Northwestern France. Atmos. Environ. 33 (20), 3377-3388.

Verna, C., 1996. Une nouvelle page de l'histoire des mines d'argent européennes: le cas des Pyrénées centrales (XIVe -XVe siècle). Bull. Annu. Société Ariégeoise Sci. Lett. Arts 201-232.

Wardenaar, E.C.P., 1987. A new hand tool for cutting peat profiles. Can. J. Bot. 65 (8), 1772-1773.

Weathers, K.C., Lovett, G.M., Likens, G.E., Lathrop, R., 2000. The effect of landscape features on deposition to hunter mountain, catskill mountains, new York. Ecol. Appl. 10 (2), 528-540.

Zheng, J., Shotyk, W., Krachler, M., Fisher, D.A., 2007. A 15,800-year record of atmospheric lead deposition on the Devon Island Ice Cap, Nunavut, Canada: natural and anthropogenic enrichments, isotopic composition, and predominant sources: a 15,800-year Pb record from Devon Island ice. Glob. Biogeochem. Cycles 21 (2). 